\author{
Бабченко Яніна Юріївна, \\ аспірантка Київського національного \\ університету культури і мистецтв, \\ ORCID 000-0003-0759-3577 \\ yanina.bambinos@gmail.com
}

\title{
ГРАФІЧНИЙ ДИЗАЙН У ПРОСТОРІ ІНФОРМАЦІЙНО-КОМУНІКАТИВНИХ ТЕХНОЛОГІЙ СУЧАСНОСТІ
}

\begin{abstract}
Мета роботи - визначити взаємодії образних та функціональних параметрів графічного дизайну як складової комунікативного простору. Методологія дослідження полягає в застосуванні аналітичного, мистецтвознавчого, функціонального, системного методів дослідження графічного дизайну в контексті формування інформаційно-комунікативних технологій як певного синтезу мистецтв. Наукова новизна дослідження полягає у визначенні сутності графічного дизайну як синтетичної сфери, яка поєднує в собі всеосяжні виміри комунікативних технологій сучасності. Висновки. У результаті здійсненого аналізу можна дійти висновку, що образ в графічному дизайні є синестезійним, визначається в тому, що домінує письмо, але воно відсилає до багатьох реалій, які ми споглядаємо як фентезі, кібер-панк, певна класика, нова хвиля та ін. Всі ці контексти та образи, звичайно, не є герметичними, вони вписуються в простір культури, так чи інакше виражають себе в письмі, промові, дискурсі реклами та естради, шоу-бізнесу, у всьому тому просторі, що можна визначити як арт-простір вистави, презентації інформаційно-комунікативних відносин.
\end{abstract}

Ключові слова: дизайн, письмо, рефлексія, артефакт, графічний дизайн, менеджмент.

Бабченко Янина Юрьевна, аспирант Киевского национального университета культуры и искусств
Графический дизайн в пространстве інформационно-коммуникативных технологий
современности

Цель работы - определить взаимодействие образных и функциональных параметров графического дизайна как составляющей коммуникативного простора. Методология исследования состоит в применении аналитического, искусствоведческого, функционального, системного методов исследования графического дизайна в контексте формирования информационно-коммуникативных технологий как определенного синтеза искусств. Научная новизна исследования состоит в определении сущности графического дизайна как синтетической сферы, которая объединяет в себе всеобъемлющие измерения коммуникативных технологий современности. Выводы. В результате проведенного анализа можно сделать вывод, что образ в графическом дизайне есть синестезийным, определяется в том, что доминирует письмо, но оно отсылает ко многим реалиям, которые мы рассматриваем как фэнтези, кибер-панк, определенная классика, новая волна и др. Все эти контексты и образы, обычно, не есть герметическими, они вписываются в пространство культуры, так или иначе выражают себя в письме, речи, дискурсе рекламы и эстрады, шоу-бизнесе, во всем том пространстве, которое можно определить арт-пространство представления, презентации информационно-коммуникативных отношений.

Ключевые слова: дизайн, письмо, рефлексия, артефакт, графический дизайн, менеджмент.

Babchenko Yanina, graduate student of the Kyiv National University of Culture and Arts

Graphic/ Design in Information - Communication Technology Space at the Contemporary period

The purpose of the article is to determine the interactions of the figurative and functional parameters of graphic design as a component of communicative space. The methodology of the study is to apply analytical, art, functional, systematic methods of graphic design research in the context of information-communication formation technology as a certain synthesis of the arts. The scientific novelty of the research is to define the meaning of graphic design as a synthetic sphere that combines the nowadays universal, capacitive dimensions of communicative technologies. Conclusions. Thus, the conglomerate of anthropological, visual, and verbal reaches in the letter of modern communication the graph-virtual language of a kind of apex. But more and more, this letter is turning into a chaosogenic environment that must seek attractors, find resting areas, epicenters that would be harmonizing. As well as this is one way or another related to the informative message to the information environment in which the graphic design works. As a result of the analysis, we can conclude that the image in graphic design is synesthetic, determined by the fact that the letter dominates, but it sends to many realities that we see as fantasy, cyberpunk, a certain classic, a new wave and more. All these contexts and images, of course, are not leaky, they fit into the space of culture, in one way or

(C) Бабченко Я.Ю., 2019 
another express themselves in writing, speech, discourse of advertising and variety, show business, in all that space that can be defined as the art space of performance, presentations of information and communication relations.

Key words: design, writing, reflection, artifact, graphic design, management.

Актуальність теми дослідження. Письмо в широкому сенсі - це й вербальна нотація тексту, візуальна нотація тексту, яка занотовує, фіксує ті артефакти культури, які є культурно актуальними. Графічний дизайн - це синтетична сфера, яка поєднує в собі виміри рекламних комунікацій, книжкової та відео комунікації. Дизайн в цілому як культурна практика теж є синтетичним явищем. 3 одного боку, - це рефлексія, дизайн осмислює те, що відбувається в просторі конструювання художніх артефактів. Це мистецтво, в якому завжди існує художній образ. Це конструктивно-будівна діяльність, де конструкція є пріоритетною, тобто визначається як певні архетипи та ознаки образності. Це менеджмент та маркетинг. Всі ці складові певною мірою створюють соціопрагматику дизайну, яка в графічному дизайні досягає свого апогею як писемність, письмо доби, як певне самовизначення графематики того, що фіксує час. Сучасний графічний дизайн - це та сфера проектної діяльності, де візуальні комунікації мають свою унікальну мову, тобто мову, орієнтовану на письмо. Можна стверджувати, що графічний дизайн - це одна 3 надзвичайно важливих конфігурацій писемності, яка дає ємний образ культури.

Мета роботи - визначити взаємодії образних та функціональних параметрів графічного дизайну як складової комунікативного простору.

Аналіз публікацій та досліджень. Проблема графічного дизайну досліджувалася в роботах Н. Межиріцької, В. Пігулєвського, О. Сенько та ін. [1; 3; 3], адже малодослідженим є контекст формування інформаційно-комунікативних технологій як певний синтез мистецтв.

Виклад основного матеріалу. Родоначальником графічного дизайну вважають міжнародний стиль, який виник у Швейцарії. Його утворили емігранти, які приїхали з Німеччини після нацистської хвилі 30-х років. Америка, Швейцарія та інші країни були заповнені тими діячами, які в Баухаузі порушували проблеми типографіки, шрифту, цілісності графічної мови та ін. «Міжнародний стиль» Швейцарії заснований завдяки дизайнеру та педагогу Вольфгангу Вайнгарту, який мріяв побудувати спільноту дизайнерів, розвивати принципи конструктивізму, що були популярними в Німеччині у 20-ті роки. Ян Чихольд - найвідоміший прихильник типографіки, був вимушений в 33-у році емігрувати з Німеччині та оселитися в Базелі, у Швейцарії. Поступово домінує конструктивізм, широка назва, яка говорить про логіку прямого кута, певну ортогональність побудови площини листа, в Швейцарії виникає реальність формотворчого синтезу графічного дизайну, яка згодом універсалізується й стає міжнародною.

Тема графіки й письма стає орієнтованою на шрифт, на носія інформації, а шрифтові композиції визначають пріоритет та конструктивний принцип міжнародного стилю. Н. Межерицька пише: «Перший шрифт, тепер відомий як Helvetica, був створений у 1953 році для Едуарда Хоффмана, власника ливарного заводу в Цюріху. Хоффман відзначив виключну популярність Gelveiik Aksidens та хотів створити альтернативи для власного бізнесу. В 1951 році він дав наказ створити новий шрифт, заснований на гротескних акциденціях. Шрифт було створено» [1, с.44].

Екстравагантність, гротеск, простота стають синтетичним образом, який утворюється в Швейцарії як широка образна парадигма. Всі ті реалії, які опрацьовувались в практиці, тут же рефлектувались. Хоффман створює теорію точки, ця віртуальна засада як модельно-конструктивний принцип домінує, дає можливість побудувати шрифт, який набирається на підставі певного групування точок растрового конструктора. Це достатньо нова ідея, але вона швидко перетворилась на цифрові технології. Можна стверджувати, що сама по собі композиція, тобто єднання образних, альтернативних, конфігуративних реалій, містить в собі декілька конструктивних засад. 3 одногу боку, - це монізм висхідного елемента, та ж точка Хоффмана, а з іншого - це метафоричність як єднання з вербальним асоціативним кодом з достатньо простими та зрозумілими словами.

Все це утворило ті ходи подальшого розвитку, коли площина розламується, шрифт починає існувати у віртуальному просторі, й, зрештою, виникає те, що можна визначити як полістилізм, який формується в тій самій школі та, зрештою, досягає свого апогею в професіональному просторі графіки Швейцарії. Важливо зазначити, що саме в ці часи стиль різко змінюється, відрізняється від 20-х років, графічний дизайн стає віртуальним, орієнтованим на дигітальні технології, які стають єдиною мовою макетування й образної презентації графічної продукції.

Серійність, візуальна та вербальна інтрига, своєрідний гумор, підтекст, асоціативність дають ознаки широкого пресингу, де графічний дизайн стає інтегративним фактором. Він поєднує в собі комунікативні ходи, смислові алюзії, а також надає домінанту - шрифтову, візуальну або таку, яку 
можна назвати синтетичною. Тобто символізм образних конструктивних шрифтових і символічних ходів та кодів дає можливість швидко сприймати складну трансформативну продукцію. Поступово графічний дизайн настільки гостро починає експериментувати з шрифтом, що шрифт перетворюється на власну мову, графематичні перехрещення й своєрідні синкретизми, що дають можливість шрифтового драматизму, який трансформує графічний дизайн у поп-арт, мистецтво, яке перетворюється на графіті, що входить в середовище міста, крім того, входить в простір побутової культури, яка часто-густо має суто графічний характер.

Графічний дизайн настільки універсалізується, що стає метахудожнім, метакультурним простором. Деформується метамова комунікації. Вона несе в собі неочікувану трансформацію масштабів алюзії, підтекст та те, що можна назвати - попса. Все це відбувається після Другої світової війни, а в 60-ті роки досягає свого апогею. Якщо говорити про пострадянський простір, то тут поки що таких гострих інновацій не існує, вони приходять у цей простір у 90-ті роки й дуже швидко адаптується в книжковій продукції, що формується як підтекст масових комунікацій.

Засоби поетики міжнародної швейцарської школи графічного дизайну належать картезіанському простору. Це простір регулярний, нормативний, будується на підставі самоздійснення тих інтенцій, які належать метризації, а не ритмізації простору. Регулярність у свій час стала основою класики, тієї конструкції, яка трималась у графіці століття. Постмодерн розмиває регулярність, виникає проблема нелінійності письма, а простір, як носій інформації, стає нелінійним, тобто площина деваліюється як засада, носій інформативних повідомлень. Відтак, відбувається певне розшарування пластів інформації, виникає зчитування інформації у вигляді лабіринту, дифузних діагональних сканувань. Тобто те, що ми звемо гіпертекстом, у графічному дизайні формується на підставі палімпсесту, просвічування пластів, своєрідного нашарування інформативних зон.

Соціопрагматика, тобто орієнтація на споживача, в постмодерністському вимірі графічного дизайну є надзвичайно полівалентною. Існує багато різних концептуальних схем графо, письма, а для непідготовленого читача лише система сіток, растрів, регулярної зчитки інформації як лінійної цілісності дискурсу зберігає жорстку систему інформаційного повідомлення. Для підготовленого вже надається образ нелінійної візуальної систематики, яка поєднує різні візуальні зони на підставі віртуальних алюзій та взаємодій.

Отже, феномен нелінійності спонукає до варіативності, своєрідної міфопоетики, яка створює імідж стереотипів світогляду тієї культури, яку ми називаємо масовою. Масова культури 3 iі домінантою кіно, музики, відеокліпів, шоу, цирку, естради й широкої презентації виставкової діяльності орієнтовна на комікс, гумор, гру сенсів, на фентезі, тобто єднання фантастики й кіберпростору. Формується напрям кібербанку, де створюється своєрідна мрія єднання людських засобів самоздійснення в контексті паранормальної дійсності, а також фольклорного синкретизму намріяного світу, єднання із сутностями, які не мають смертної форми існування.

Створюється неоміфологія, якщо не утопія, де людина тікає у світ фентезі, що розширює можливості алюзій. Тобто людина існує на межі справжнього та несправжнього світу. Втеча в несправжній світ завжди межує з соціопрагматикою, шоу-бізнесом, а сам міф ідеального образу життя водночас усувається, набуває своєрідної прагматики, яка стає мальованою картинкою відфотошоплених, трансформованих на екрані форм та різних ігрових конфігурацій, які виносять на поверхню гіпермаріонетку. Це символ, лялька і водночас а́ктор, гравець зі світом, долею.

В. Пігулєвський пише: „Фентезі виникає як трансформація сплаву епосу, готичного авантюрного лицарського роману, фейної казки (fairu tates), історії про духи як окремий жанр. Історично першими складувались героїчні фентезі в У. Moppica (романи 1988-1897). Тут романтичний герой сам на сам протистоїть труднощам і випробуванням, переміщається в казковий простір з певною місією (guest - англ.: шлях пошук): пошуку себе, гармонії або спасіння світу. На початку XX століття традицією було продовжено: «Дочка короля ельфів» У. Дансенйні, «Конанварвар» Р. Говарда. Так Конан і Тарзан описуються як герої, котрі вирішують проблеми за допомогою думок, сили та винахідливості. Міфотворчість полягає в зануренні в контекст світу або природи, котрі протиставляються сучасній цивілізації. Як правило, герої поділяються на позитивних і негативних у конфлікті світла й темряви" [2, с.90].

Графічний дизайн стає монтажем картинок, намріювань, а якщо це кібербанк, якщо це створені на екрані істоти, то виникає світ надреальний, де комунікація з істотами, що не мають смертної форми існування, стає найголовнішим образним епіцентром. Тобто фентезі - це своєрідна казка, яка створює новий міф, власне тут все можливо: алюзії, творчість, нові винаходи, пов'язані зі слоганом, логоцентризм, де аудіальний простір повниться шумами, тією музикою, що пов'язують із сонорикою, з ідеєю міксування шумів і ритмів музики, а також побутових мелодій та класики. 
Таке рухливе перехрестя так чи інакше пов'язується 3 нелінійним простором, де існують квазіартефакти, а домінантою постає монтаж, система віртуального письма, яка в графічному дизайні створює візуальну квазіграфематику, або нову візуальну мову, яка відрізняється від звичайної, асоціюється з поетикою вулиці, урбанізованого середовища й реклами. „Фентезі дозволяє активізує тілесний досвід людини й віру в паранормальні здібності, надприродні розуміння людини телепатію, телекінез, левітацію, обернення, магію та ін. Реальні бажання дозволяють звернути увагу на тілесно-чуттєвий досвід, прихований за нашаруванням раціоналізму та соціальних ролей, відчути свою єдність 3 природою. Людина може згадати, що вона також має тіло, як тварина, 3 його потребами бігати, гратись, плавати, відчуває фізичну радість. Згадати перше враження весни, любові, плавати, як риба, але не з аквалангом, літати як птах, але не на літаку, чути запахи, як тварина, а не вдихати аромати парфумів” [2, с.95].

Та реальність, яка конструюється на екрані, створює нову систему письма, нову мову справжніх почуттів. Створюється нова естетика фентезі, яка конструюється на основі нелінійного простору, і знову ж таки ця нелінійність корелює з паранормальними явищами і всім тим, що тілесний кінетичний досвід піднімає на п'єдестал. Тобто рефлексія фентезі - це подвоєння світів, синтез двох вимірів світотворення - комунікативного та містичного. Таким чином виникає надмірність бажань і надмірність задоволення цих бажань. Мова презентації інформації базується на механізмі синекдохи, коли ціле презентується частиною, або, навпаки, частина презентується цілим. Це достатньо простий код, а в його оболонці вербальних та візуальних конфігурацій утворюється той контекст, який озвучує графічний дизайнер. Відтак, можна сказати, що за тілесним досвідом стоїть ерос в широкому чуттєвому розумінні, де міфологія походить від античності, досягає свого рефлексивного образу, який не просто використовує оголене тіло, зокрема жіноче, а намагається перетворити його на гіперсилу, починає заміщувати його лялькою. Так сексуальні ляльки, ляльки в грі та презентація ювенальності тіла як лялькоподібна реальність стає маріонеткою сучасного графічного дизайну як новітня мова фентезі, яка ні до чого не веде, яка ні до чого не зобов'язує. Але тут відбувається трансгресія, перехід всіх меж.

В. Пігулєвський пише: «Еротика може бути розфарбованою мотивами інверсій, такими як садизм і мазохізм, содомія, геронто-, некро-, зоофілія або сюжетом гомосексуальної еротики, однак будь-яка трансгресія перетворюється тут на реальність особового роду, де діє вже не стільки мораль, скільки «логіка почуттів. Тому культурні заборони знімаються художньою формою, а еротичне виражається засобами трагічного або комічного, в формі гумору, пародії, бурлеску, драми та ін. Найбільшої сили афект досягає не завдяки враженям пристрасті, а завдяки зображально-виразовим засобам»[2, с. 99].

Тобто проблема ню та еротично прекрасного тіла так само стара, як світ, але є надзвичайно драматичною в сучасних реаліях масової культури. Ми маємо гламурну модель еротичного як своєрідний глянцевий світ модельних журналів з його графематикою, маємо еротику в рекламі, де еротичне проектується на товари, послуги, виникають бренди, виникає безкінечно щасливе життя завдяки тому, що людина купує той чи інший продукт. Так створюється культ споживання в масовій культурі, який так чи інакше стає симулятивним, еротико травматичним і водночас театральним простором.

Графічний дизайн в такому розумінні створює тіло бажань, своєрідну атмосферу, яку дуже важко зазначити в контексті того, що можна охарактеризувати як любов в різних іiі проявах - любов безкорисливу, фізичну та ін. Ми маємо перед собою симулятори, маємо той образ, який досягає своєї межової й водночас етично продукованої реальності візуального простору порноанімації. «Порнофільми, - пише В. Пігулєвський, - $є$ своєрідним комерційним фетишем в культурі споживання... Популярність порноанімації говорить про те, що молодим людям важко мати інтимні почуття. I причиною $є$ вихолощування сенсу любові в умовах наявного дискурсу та репресивних норм культури» [2, с.109].

Дизайн як мистецтво є конфігурацією образних імплікацій, а в цьому разі анімацією, грою на межі, усуванням етосу, будь-якою етикою, грою в умовність, де лялькоподібні та манекеноподібні еротичні об'єкти, а фактично постаті, які не мають смертної форми існування, демонструють «найбільш міцний, енергійний і могутній» секс. Все це в лапках, звичайно. Можна стверджувати, що надмірна еротизація, комерційний еротизм стає комунікативним маркером культури, і не лише масової культури. Культури, яка позбулася найголовнішого, - сорому. Якщо зараз «демократичні країни» намагається упорядкувати рівноправ'я в шлюбі, гомогенних і гетерогенних, то, звичайно, це призводить до того, що скоро людина буде одружуватися 3 манекенами, ляльками й легко трансформувати свою подобу, свій образ. 
Можна стверджувати, що це новітнє письмо, новітній дискурс, який повинен мати свій дизайн, ідеальний дизайн. Він і зветься умовно «еротичним дизайном». Цей дизайн, як комунікативний арт-феномен, $\epsilon$ сучасним, агресивним і водночас полівалентним, тобто не протиставляє реальність нереальності, жіноче - чоловічому, все поєднується, заміщується, все тече та перетворюється одне в інше. Така негативна діалектика спонукає до осмислення тих комунікативних фантомів, які вже далеко вийшли за межі картезіанського ergo sum, взагалі, за центрацію свідомості та за межі екології сприйняття. Перед нами екологія небачення або екологія надбачення, коли об'єктив бачить все, спонукаючи не бачити головне, не бачити духовного, глибинного людського сенсу буття.

Отже, графічний дизайн концентрує в собі потенціал антропологічного, семіологічного та візуального поворотів. Антропологічний поворот визначається тим, що виникає проміжна мова між істотами, що не мають смертної форми існування, кіборгами та істотами масової культури. Суб'єкт культури стає симультанним суб'єктом, який є продуцентом і реципієнтом одночасно. Семіологічний поворот свідчить про те, що формується логографія, сучасна метамова, яка концентрує вербальний дискурс у певних візуальних артефактах, які нагадують шифр, еротичні гіперсимволи, що формалізується в шрифтових імплікаціях, які є досить різноманітними. Образний ряд мімікрує від класики міжнародної швейцарської школи дизайну до сучасного нелінійного вербального дискурсу. Візуальний поворот визначається тим, що формується світ паралельної намріяної реальності, фентезі, як завгодно можна називати, - симулякрів, що вже стали певним штампом. Адже це не просто симуляція реальності - це виникнення надреальності, яка апелює до міфології, стає певним архетипом, а також відповідає глибинним потребам людини, зокрема сексуальності.

Цей конгломерат антропологічного, візуального й вербального досягає в письмі сучасної комунікації графо-віртуальної мови своєрідного апогею. Але все більше й більше це письмо перетворюється на хаосогенне середовище, що повинне шукати атрактори, знаходити зони спокою, епіцентри, які були б гармонізуючими. А це, так чи інакше, пов'язано 3 інформативним повідомленням, з тим інформаційним середовищем, в якому працює графічний дизайн.

Відтак, виробництво нових і більш нових обсягів текстової інформації, а також своєрідна символологія, рефлексія над метатекстуальною реальністю призводить до того, що за доби глобалізації, зокрема в контексті постмодерної культури, відбувається своєрідна девальвація письма, письмо заміщується картинкою. В кращому разі відбувається своєрідна піктографізація письма. Можна стверджувати, що феномен глянцевих журналів, коміксів, інтернет в певній мірі заперечують все те, що пов'язане з книгою, типографікою, а цифрові технології дають можливість, з одного боку, урізноманітнити шрифти, а з іншого - вони все більше й більше стають уніфікованими. Фантоми дизайнерських інновацій не приживаються. Людина в потоці вербальних та візуальних спекуляцій шукає коридори загальнодоступної інформації та загальнодоступних регістрів інформації.

Тобто, можна сказати, що графічний дизайн переживає стадію стагнації, стадію спрощення, тяжіння до достатньо чітких конфігурацій. Починають цінуватись силует, коли форма все більше стає пластичною, але у віртуальному просторі форма заміщується у силуетному просторі зчитуванням інформації на краї «ядерним етосом» візуальної риторики. Систематика текстових повідомлень, розкидування зон, визначення центральних, сакральних артефактів і периферійних все більше усувається, ми потрапляємо в осьовий простір, де домінують зсунуті та зламані осі, вертикалізація інформації стає однією з найголовніших норм її гармонізації. Вертикаль прочитується імпліцитно як своєрідна вісь самостояння людини, на яку нанизуються всі можливі конфігурації.

Можна стверджувати, що одним із напрямів дисфункції, переструктурування водночас поліморфності графічного дизайну стає архаїзація, що призводить до своєрідної вертикалізації тексту. О. Сєнько визначає декілька напрямів презентації графічного дизайну: «Умовно можна визначити тренди графічного дизайну стосовно яких розкривається кітч: „квазікласика” як концепція, що була панівною до 1970-х років, являє собою репрезентацію «високих казок», консервацію композиційних правил, звернення до національного художнього фольклору та підкресленої декоративності. Образам властива художність, додаткове ідейне навантаження - «прагнення до респектабельності» або «результативності». Ці особливості концепції сприяють виокремленню прикладної графіки; функціоналізм, вираженням якого став міжнародний швейцарський стиль, ототожнюється 3 модульною сіткою, шрифтовим мінімалізмом, документальною чорно-білою графікою. В основу даної концепції покладена візуально-комунікативна складова за умови максимального ступеня умовності; «Нова хвиля» визначає абсурдність і непередбаченість графічних рішень. У виробництві «нової хвилі» отримують права громадянства аматорські шрифти, в котрих немає й натяку на функціональність. Ця тенденція стала переворотом композиційних принципів 
цілісності, єдності, урівноваженості й відкрила нові виразні можливості візуального рішення об'єкта, використання різних фактур, текстур, площин та ін.» [3, с. 152-153].

Наукова новизна дослідження полягає у визначенні сутності графічного дизайну як синтетичної сфери, яка поєднує в собі всеосяжні виміри комунікативних технологій сучасності.

Висновки. Можна стверджувати, що образ у графічному дизайні $є$ синестезійним, визначається в тому, що домінує письмо, але воно відсилає до багатьох реалій, які ми споглядаємо як фентезі, кібер-панк, певну класику, нову хвилю та ін. Всі ці контексти та образи, звичайно, не $є$ герметичними, вони вписуються в простір культури, так чи інакше виражають себе в письмі, промові, дискурсі реклами та естради, шоу-бізнесу, у всьому тому просторі, що можна визначити як артпростір вистави, презентації інформаційно-комунікативних відносин.

\section{Jimepamypa}

1. Межерицкая Н.В. Швейцарский Международный стиль. Визуальные коммуникаиии в рекламе и дизайне. Харьков: Гуманитарный центр, 2011. С. $37-81$.

2. Пигулевский В.О. Жанры массовой коммуникации и графический дизайн. Визуальные коммуникации в рекламе и дизайне. Харьков: Гуманитарный центр, 2011. С. 81 - 112.

3. Сенько О.В. Китч в графическом дизайне России. Визуальные коммуникаиии в рекламе и дизайне. Харьков: Гуманитарный центр, 2011. С. $132-155$.

\section{References}

1. Mezheritskaya N.V. (2011). Swiss International Style, Visual communications in advertising and design, Kharkiv: Humanitarian Center, 2011. 37-81. [in Russian].

2. Pigulevsky V.O. (2011). Genres of mass communication and graphic design, Visual communications in advertising and design. Kharkiv Humanitarian Center, 81 - 112. [in Russian].

3. Senko O. V. (2011). Kitsch in Russian graphic design, Visual communication in advertising and design. Kharkiv: Humanitarian Center, 132 - 155. [in Russian]. 